RESEARCH ARTICLE

\title{
How groundwater level can predict under the effect of climate change by using artificial neural networks of NARX
}

\author{
Safieh Javadinejad ${ }^{1^{*}}$ Rebwar Dara $^{1} \quad$ Forough Jafary $^{1}$ \\ ${ }^{1}$ Department of Water Resource Engineering, University of Birmingham, Edgbaston St., B152TT, UK
}

\section{Check for updates}

Correspondence to: Safieh Javadinejad, Department of Water Resource Engineering, University of Birmingham, Edgbaston St., B152TT, UK;

E-mail: javadinejad.saf@ut.ac.ir

Received: September 30, 2020;

Accepted: December 27, 2020;

Published: December 29, 2020

Citation: Javadinejad S, Dara R and Jafary F. How groundwater level can predict under the effect of climate change by using artificial neural networks of NARX. Resour Environ Inf Eng, 2020, 2(1): 90-99. https://doi.org/10.25082/REIE.2020.01.005

Copyright: (c) 2020 Safieh Javadinejad, et al. This is an open access article distributed under the terms of the Creative Commons Attribution License, which permits unrestricted use, distribution, and reproduction in any medium, provided the original author and source are credited.

\begin{abstract}
The phenomenon of climate change in recent years has led to significant changes in climatic elements and as a result the status of surface and groundwater resources, especially in arid and semi-arid regions, this issue has sometimes caused a significant decline in groundwater resources. In this paper, the effects of climate change on the status of groundwater resources in Marvdasht plain have been investigated. Water supply of different parts of this region is highly dependent on groundwater resources and therefore the study of groundwater changes in future periods is important in the development of this plain and the management of its water resources In order to evaluate the effects of climate change, the output of atmospheric circulation models (GCM) has been used. Then, in order to adapt the output scale of these models to the scale required by local studies of climate change, precipitation and temperature data have been downscaled by LARS-WG model. Downscaled information was used to determine the amount of feed and drainage of the aquifer in future periods. To investigate changes in groundwater levels at different stages, a neural network dynamic model has been developed in MATLAB software environment. It is also possible to study and compare other points using other scenarios and mathematical modelling. The results of the study, assuming the current state of development in the region, indicate a downward trend in the volume of the aquifer due to climate change and its effects on resources and uses of the study area. The results also introduce Scenario A2 as the most critical scenario related to climate change, which also shows the largest aquifer decline in neural network modelling.
\end{abstract}

Keywords: groundwater, climate change, microscalling, NARX neural network

\section{Introduction}

Climate change has a significant impact on groundwater and surface water resources. Due to the fact that the impact of climate change on groundwater resources is indirect and slower than surface water resources.

Monitoring the status of these resources and maintaining their sustainability under the influence of these changes is of great importance. In this regard, various studies by [1-3] on surface water on groundwater recharge [4-6], and on groundwater level [7-10] on the sensitivity of the coastal aquifer using mathematical models and Physics has been done to assess the effects of climate change. Also, [11] and [12], modelling on groundwater and [13] has modelled the aquifer using the neural network model. In the following, we will review the studies conducted. [14] investigated the effect of climate change scenarios on rainfall and temperature and consequently changes in the water level of the Great Lakes of North America The results of the study show that the pure water supply of large lakes decreases in response to climate change. [15] Using information from the downscale output of large-scale climate models according to studies by [16-19] and applying two parameters of precipitation and evaporation Giving this information in a hydrological model, the effects of climate change on groundwater recharge and soil moisture have been investigated. The results of this study show that climate change has a direct effect on two parameters of precipitation and evaporation. [20] using a hydrogeological model based on geological, hydrogeological and geochemical information and also by closing a linear regression of the precipitation model for the next 20 years showed that the groundwater level is gradually affected by climate change and reduced.

[21-23] were able to study the effect of climate change on the groundwater resource system in Morocco by using the moving average method. The results of this study using a numerical model show that coastal aquifers are less sensitive to precipitation changes. [24-26] used a 
combination of hydrological modelling using neural networks and climatic modelling using a fuzzy inference system for long-term Zayandehrud river volume at the inlet to the Zayandehrud dam. In this study, modelling using neural network was used indirectly in a long-term prediction structure. This trend is also seen in the [27-32].

[33-37] evaluated the capabilities of artificial neural networks in modelling the aquifer of Tabriz complex. In this study, different structures of artificial neural networks have been used to predict the water table of this aquifer in the central piezometer. Among the various structures used, the best results are related to networks Leading artificial neuron with Lunberg-Algorithm Marcourt (FNN-LM). In the next step, this structure was used to predict the water table of 8 selected piezometers in the region. The results obtained from the presentation of a single model for predicting the water level of 8 selected piezometers did not seem desirable. For this purpose, the selected piezometers were divided into two categories and a single model was presented for each category. By increasing the number of output nodes of each model to the number of piezometers in each category, two models with acceptable results were obtained. These results were able to provide a monthly forecast of groundwater water level in selected piezometers over a period of two years. The purpose of this study is to investigate the effects of climate change on the groundwater status of Marvdasht plain located in the western part of Iran, which is an arid to semi-arid region. For this purpose, first, using the output of GCM model, precipitation and temperature information have been micro-scaled and simulated under the influence of climate change scenarios for the coming years. The values of groundwater piezometric surface height in future periods have been determined, assuming that the current state of development of the region is maintained and according to the downscaled results, and the status of the aquifer in future periods has been simulated. The following is a description of the case study and the method of doing the work, discussing the results and conclusions of the research.

\section{Case study}

Case study of Marvdasht plain study area with geographical location, longitude $63^{\circ} 39^{\prime}$ to $73^{\circ} 40^{\prime}$ East and latitude $32^{\circ} 31^{\prime}$ to $33^{\circ} 35^{\prime}$ North has a total area of 2037 square kilometers. It is located in the center of Tasht-Bakhtegan watershed area which is the semi-arid area. The important rivers in the Marvasht are Kor and Sivand. Figure 1 shows the geographical location of this basin with the wells.

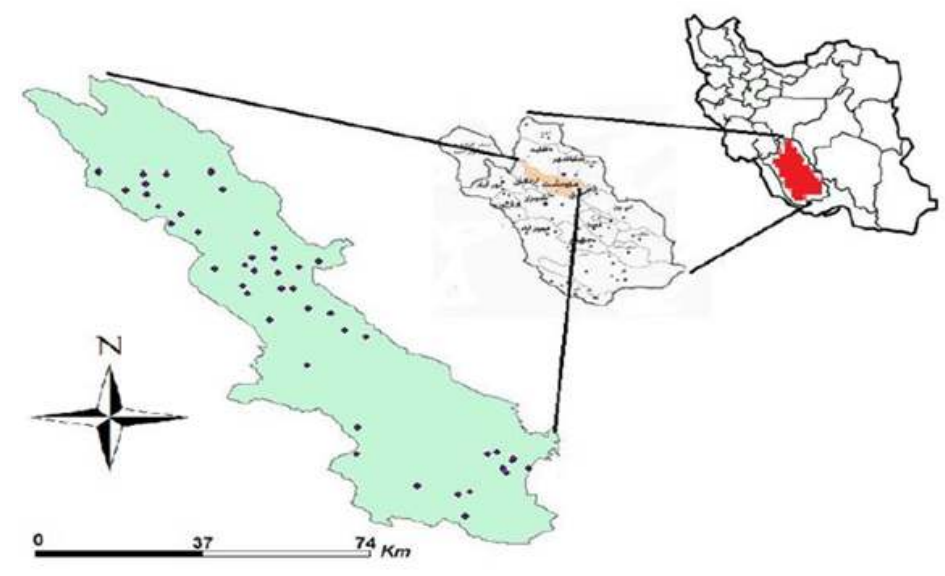

Figure 1 Location of the study area

\section{Materials and methods}

In this paper, observational meteorological information including daily precipitation, minimum and maximum daily temperature from 1980 to 2010, Ramhormoz Synoptic Station, in order to evaluate the effects of climate change, the output of atmospheric circulation (GCM) models has been used. Then, in order to adapt the output scale of these models to the scale required by local studies of climate change, precipitation and temperature data have been downscaled by LARS-WG model. Downscaled information was used to determine the amount of feeding and drainage of the aquifer in future periods. Then, in order to predict the decrease of 
groundwater level with artificial neural network model, 23 active piezometric wells in Marvdasht plain with data collected with a period of 20 years have been used to model the neural network. The NARX dynamic neural network model was developed in MATLAB software environment and the values of the simulated input components were entered into the neural network model due to climate change and the aquifer status was predicted for a future period of 7 years. The effect of climate change on the status of the aquifer is assessed assuming that the existing conditions for the development of the region are maintained. It should be noted that long-term predictions increase the probability of error occurring, so the shorter the time period selected, the less error is associated.

\section{Model of LARS-WG}

The LARS-WG model can simulate the information of a meteorological station under current and future climatic conditions. The required information is the model of daily time series of precipitation $(\mathrm{mm})$, minimum and maximum temperature $\left.{ }^{\circ} \mathrm{C}\right)$ and sunny hours $(1-(\mathrm{MJ}$ $\mathrm{m}-2$ day). A1B and B1 were performed, showing the most critical conditions as Scenario A2, during the precipitation microscaling steps using the LARS-WG model, to obtain the statistical characteristics of dry and wet days and the average daily precipitation per month of the year at the station. Ramhormoz, the observational daily rainfall time series was analyzed on a monthly basis.This information was used to develop the quasi-experimental distribution of dry and wet daily series duration and daily rainfall and using these semi-experimental distributions, random values For daily series of dry and wet days for each month of production, also the amount of precipitation was produced from the semi-experimental distribution of precipitation.

To perform the sensitivity analysis of the input pattern, the Kolmogorov-Smirnov (KS) and t-test statistical validation methods were used, and thus the calculated values were compared with the observed ones, and the calculated values that were closer to the observed values and had less error and more validity were selected.

\section{Artificial neural networks of NARX}

The NARX neural network model can be represented by Equation (1).

$$
\mathrm{Y}(\mathrm{t})=\mathrm{f}\left(\mathrm{y}(\mathrm{t}-1), \mathrm{y}(\mathrm{t}-2)_{\ell} \ldots \mathrm{yy}(\mathrm{t}-\mathrm{ny}), \mathrm{u}(\mathrm{t}-1), \mathrm{u}(\mathrm{t}-2), \mathrm{u}(\mathrm{t}-\mathrm{nu})\right.
$$

$\mathrm{u}(\mathrm{t}-2), \ldots \mathrm{u}(\mathrm{t}-\mathrm{nu})$, which is the value of the dependent output $(\mathrm{y}(\mathrm{t})$ based on the outputs of the previous steps and the independent values of the external input signal. it has been shown.

The NARX network output of Equation 2 is considered as an estimate of a non-linear dynamic system (Figure 2).

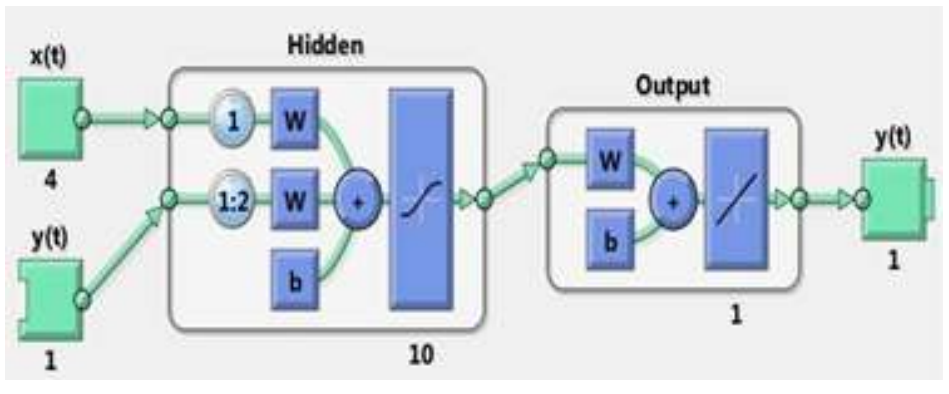

Figure 2 View of NARX neural network simulation

$$
\mathrm{Y}(\mathrm{t}+1)=\varphi 0\left\{\mathrm{wb} 0+\sum \mathrm{wh} 0 . \varphi \mathrm{h}\left(\mathrm{wh} 0+\sum \text { wihu }(\mathrm{t}-\mathrm{i})+\sum \text { wih. } \mathrm{y}(\mathrm{t}-\mathrm{j})\right)\right\}
$$

In the Equation (2), $\mathrm{Y}(\mathrm{t}+1)$ is the predicted time series of precipitation and temperatureand $\mathrm{y}(\mathrm{t}), \mathrm{y}(\mathrm{t}-1), \ldots, \mathrm{y}(\mathrm{t}-\mathrm{d} \mathrm{y})$ to(Output) indicates $(.-\mathrm{U}(\mathrm{t}), \mathrm{u}(\mathrm{t}-1), \ldots, \mathrm{u}(\mathrm{t}$ as past output data (water level du)) which is introduced as underground time series). Figure 3 shows a view of past observations (meteorological signals such as neural network predictions).

According to the hydrogeological characteristics, in addition to monthly precipitation data, temperature and sunny hours and piezometric surface height and data generated by LARS-WG monthly precipitation, minimum temperature and maximum temperature and sunny hours as the input for the selected neural network. First, the monthly data of precipitation, temperature and sunny hours and the height of the piezometric surface were entered into the artificial neural network model for simulation and then the model was connected between the 4 simulated inputs 


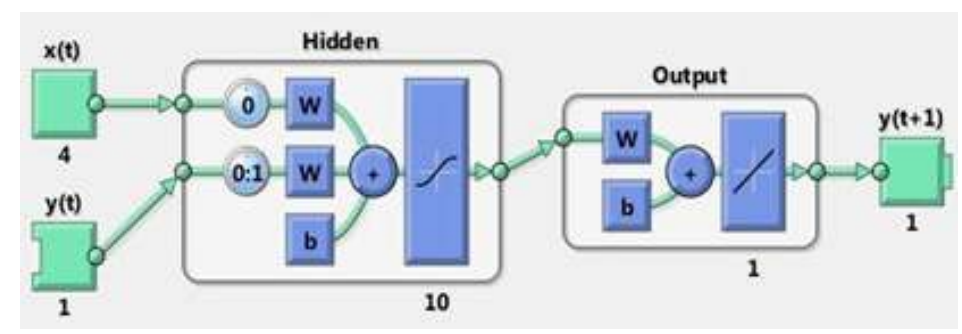

Figure 3 A view of the NARX neural network prediction

and outputs (piezometer height) and reconnected them. As input and simulate the rate of decline for the next month, then the simulated data is entered into the NARX neural network model for prediction and the one-month delay model is eliminated and forecasted for the next month based on the initial conditions. Pay. According to the time interval used to predict the height of the piezometric surface, the NARX neural network model repeated the above steps for 74 months.

In the NARX neural network model, due to the heterogeneity of the input measurement criteria, data standardization was used and the error evaluation and correlation coefficient (2RMSE) (R) were used and the calculated values were compared with the observed ones. For calibration of Marvdasht plain aquifer, water balance information of 1988-2010 has been used. Calibration parameters include minimum and maximum precipitation and temperature. Calibration error was evaluated using RMSE index.

In the above relation yi is the observational results, $y \wedge$ is the computational results and $\mathrm{N}$ is the total number of observations. RMSE shows the difference between the observed value and the calculated values. The lowest RMSE value indicates the highest prediction accuracy. Also, $\mathrm{R}^{2}$ indicates the network efficiency (Equation 4). The optimal answer for the model will be created when the RMSE tends to zero and $\mathrm{R}^{2}$ tends to one.

\section{Results}

The results are shown in Table 1. By comparing the test results with the number extracted from the table for this test, it can be concluded that the statistical distribution of data is more appropriate than the distribution of observational data in the acceptable range.

Table 1 Respondents' profile

\begin{tabular}{|c|c|c|c|c|c|c|}
\hline \multirow{2}{*}{ Month } & \multicolumn{2}{|c|}{ Precipitation } & \multicolumn{2}{|c|}{ Minimum temperature } & \multicolumn{2}{|c|}{ Maximum temperature } \\
\hline & KS-test & t-test & KS-test & t-test & KS-test & t-test \\
\hline Jan & $0 / 08$ & $0 / 69$ & $0 / 11$ & $0 / 11$ & $0 / 16$ & $0 / 01$ \\
\hline Feb & $0 / 17$ & $0 / 53$ & $0 / 11$ & 0/08 & $0 / 11$ & $0 / 26$ \\
\hline Mar & $0 / 20$ & $0 / 86$ & $0 / 05$ & $0 / 02$ & $0 / 05$ & $0 / 15$ \\
\hline Apr & $0 / 10$ & $0 / 27$ & $0 / 11$ & $0 / 63$ & $0 / 11$ & $0 / 20$ \\
\hline May & $0 / 28$ & $0 / 90$ & $0 / 05$ & $0 / 38$ & $0 / 05$ & $0 / 53$ \\
\hline Jun & $0 / 36$ & $0 / 67$ & $0 / 11$ & $0 / 29$ & $0 / 16$ & 0/06 \\
\hline Jul & 0,2 & $0 / 87$ & $0 / 11$ & $0 / 97$ & $0 / 10$ & $0 / 64$ \\
\hline Aug & 0,23 & $0 / 19$ & $0 / 11$ & $0 / 65$ & $0 / 10$ & $0 / 15$ \\
\hline Sep & $0 / 42$ & $0 / 30$ & $0 / 05$ & $0 / 89$ & $0 / 11$ & $0 / 90$ \\
\hline Oct & $0 / 31$ & 0/98 & $0 / 11$ & 0/06 & $0 / 08$ & $0 / 32$ \\
\hline Nov & $0 / 20$ & $0 / 12$ & $0 / 05$ & $0 / 84$ & $0 / 10$ & $0 / 82$ \\
\hline Dec & $0 / 03$ & $1 / 00$ & $0 / 05$ & $0 / 30$ & $0 / 05$ & $0 / 51$ \\
\hline
\end{tabular}

Note: KS-test: Dn, $\alpha=0.390,(\alpha=0.05, \mathrm{n}=12), \mathrm{t}$-test: $\mathrm{t} \alpha, \nu=2.57,(\alpha=0.05, \nu=\infty)$

According to Figure 4(a), 4(b), if the emission trend is according to Scenario A2, the average maximum and minimum temperatures will increase by a maximum of 1.9 degrees in the next 30 years, respectively. Due to the need for simulated temperature information to investigate the effect of climate change on groundwater, the average between the minimum and maximum temperature values has been averaged.

Also in Figure 4(c), a change in precipitation pattern (reduced rainfall) is observed, especially in the late months of autumn and early winter.

Results of NARX neural network model

For calibration, the NARX neural network model is given, which is based on the lowest error and the amount of error and correlation coefficient in Table 2 shows the highest correlation. 


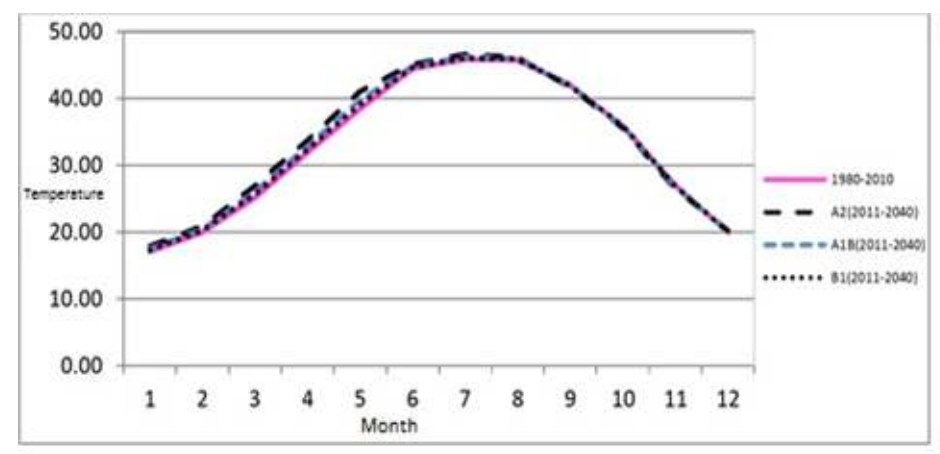

(a) Mean of maximum temperature

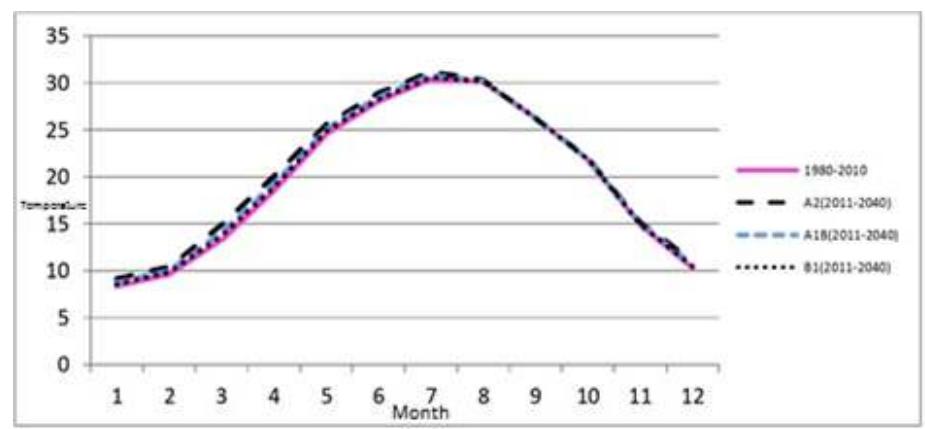

(b) Mean of minimum temperature

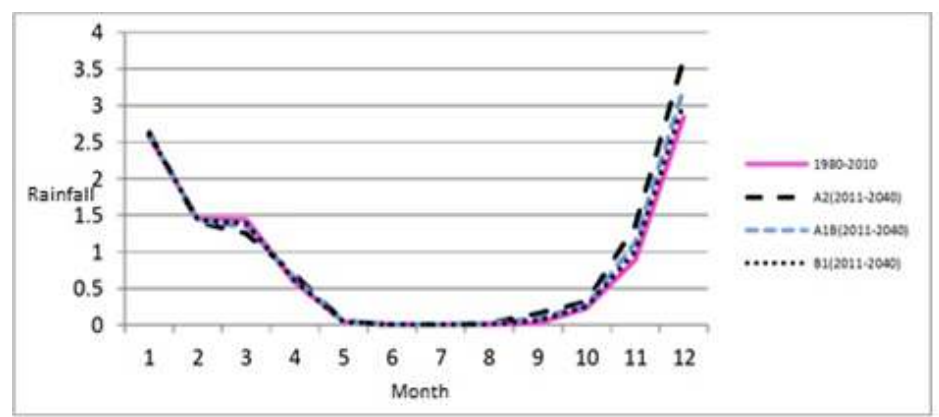

(c) Mean of precipitation

Figure 4 Comparison between observational and simulated values of LARS-WG model under scenarios A2, B1, A1B

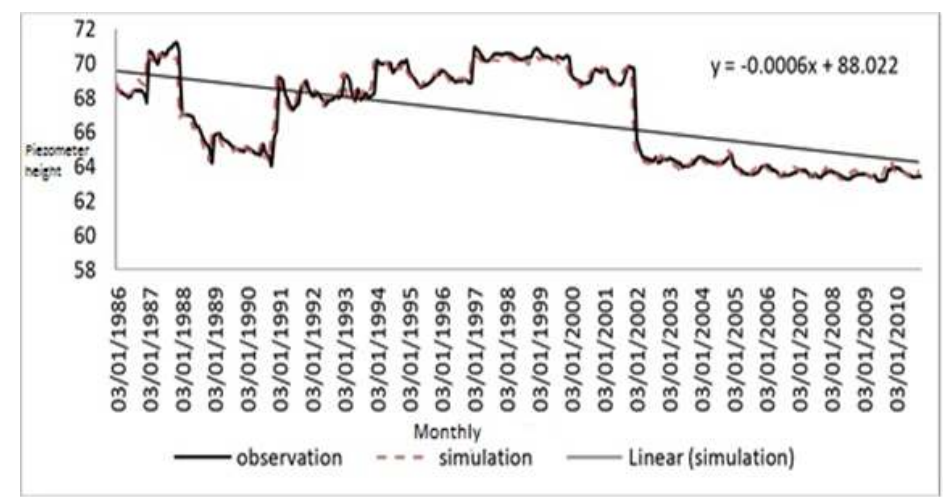

Figure 5 Average of several piezometric well samples away from the river (simulated) Evaluation of the effect of climate change on groundwater resources in Ramhormoz plain 
Table 2 Results of performance evaluation of NARX neural network model based on less error and more correlation

\begin{tabular}{lcccr}
\hline \multicolumn{4}{c}{ Compare results and evaluate errors in selecting the best simulation } \\
\hline Well characterization & \multicolumn{2}{c}{ Correlation coefficient } & Error \\
\hline & $\mathrm{R}^{2}$ & Nash_Sutcliffe & RMSE & MAE \\
8 wells & 0.93 & 0.89 & 0.25 & 0.160 \\
15 wells & 0.78 & 0.76 & 2.7 & 1.530 \\
Mean of wells near river & 0.91 & 0.85 & 3.18 & 1.730 \\
Mean of wells far from river & 0.88 & 0.82 & 0.2108 & 0.148 \\
\hline
\end{tabular}

The most important parameter affecting groundwater recharge is precipitation, so the aquifer recharge component is considered as a linear function of precipitation in the base year (19882010 balance). According to the results of LARS-WG model under climate change scenarios B1, A2, A1B of aquifer balance components in the period 2040-2011 for several piezometric wells by entering the results of LARS-WG model in neural network model and level prediction Groundwater assuming that the level of development of the region remains constant in Table 3 and 4 , it is shown that the results of the simulated water level under scenarios B1, A2, A1B in the period 2040-2011 based on the distance of piezometric wells with the upper river (middle Plain and close to Ramhormoz synoptic station (measured), which compares the level of groundwater with the amount of precipitation and groundwater nutrition with the neural network model NARX is calculated. And Scenario A2 shows more critical conditions based on the severity of water loss in piezometric wells.

Table 3 Comparison of observed and simulated water levels under scenarios A1B, B1, A2 over time 2011-2040 For some examples of piezometric wells far from the river

\begin{tabular}{ccccc}
\hline $\begin{array}{c}\text { Calculated level of } \\
\text { groundwater B1 } \\
(\mathrm{m})\end{array}$ & $\begin{array}{c}\text { Calculated level of } \\
\text { groundwater A1B } \\
(\mathrm{m})\end{array}$ & $\begin{array}{c}\text { Calculated level of } \\
\text { groundwater A2 } \\
(\mathrm{m})\end{array}$ & $\begin{array}{c}\text { Observed level of } \\
\text { groundwater } \\
(\mathrm{m})\end{array}$ & $\begin{array}{c}\text { Number of } \\
\text { piezometer }\end{array}$ \\
\hline 63.41 & 63.01 & 62.02 & 68.51 & 3 \\
71.05 & 70.80 & 70.65 & 82.51 & 4 \\
66.93 & 66.80 & 66.34 & 76.71 & 5 \\
68.86 & 68.53 & 68.3 & 75.85 & 8 \\
63.91 & 63.64 & 63.01 & 70.51 & 27 \\
\hline
\end{tabular}

Table 4 Comparison of observed and simulated water levels under scenarios A1B, B1, A2 over time 2011-2040 For some examples of piezometric wells near the river

\begin{tabular}{ccccc}
\hline $\begin{array}{c}\text { Calculated level of } \\
\text { groundwater B1 } \\
(\mathrm{m})\end{array}$ & $\begin{array}{c}\text { Calculated level of } \\
\text { groundwater A1B } \\
(\mathrm{m})\end{array}$ & $\begin{array}{c}\text { Calculated level of } \\
\text { groundwater A2 } \\
(\mathrm{m})\end{array}$ & $\begin{array}{c}\text { Observed level of } \\
\text { groundwater } \\
(\mathrm{m})\end{array}$ & $\begin{array}{c}\text { Number of } \\
\text { piezometer }\end{array}$ \\
\hline 121.23 & 120.11 & 119.01 & 123.65 & 11 \\
101.33 & 100.77 & 99.67 & 103.52 & 15 \\
152.1 & 151.61 & 150.01 & 182.83 & 19 \\
153.01 & 152.76 & 152.11 & 190.42 & 38 \\
135.26 & 135.01 & 134.11 & 155.81 & \\
\hline
\end{tabular}

Figure 5 shows the validation of the NARX neural network model in the period 1988-2010. In this way, the height of the observed piezometers is matched with the height of the piezometers simulated by the NARX neural network model. The height of the observational piezometers obtained from the information received from the Regional Water Organization was selected based on the averaging of several well samples in the northwest of the plain with the maximum distance from the upper river and compared with the height of the piezometers simulated by the neural network model. . In Figure 6, the height of observation piezometers located in the southeast of the plain with the minimum distance from the river is selected and compared with the height of the simulated piezometers with the neural network model.

As Figure 7 and 8 show, the groundwater level is decreasing in all parts of the aquifer, so a suitable plan to improve the aquifer and limit groundwater abstraction in this plain, especially in the southeast of the plain should be considered. However, due to the high river, the drop in groundwater level has received less attention. Also, according to the neural network modeling for all three scenarios, it is quite clear that the rate of decline in all three scenarios over a period of 30 years is almost the same, although in scenario A2 I see more decline in the aquifer, if the 


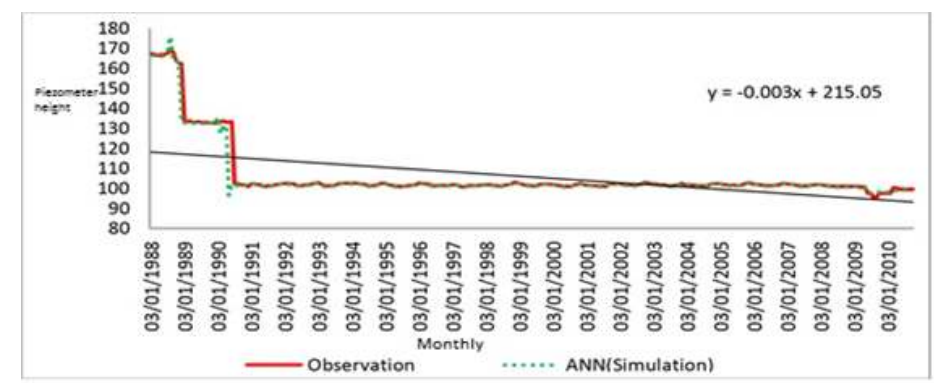

Figure 6 Mean of several piezometric well samples near the river (simulated)

same conditions in terms of nutrition And if the aquifer is drained in the future, we will see the possibility of further aquifer decline over longer periods of time.

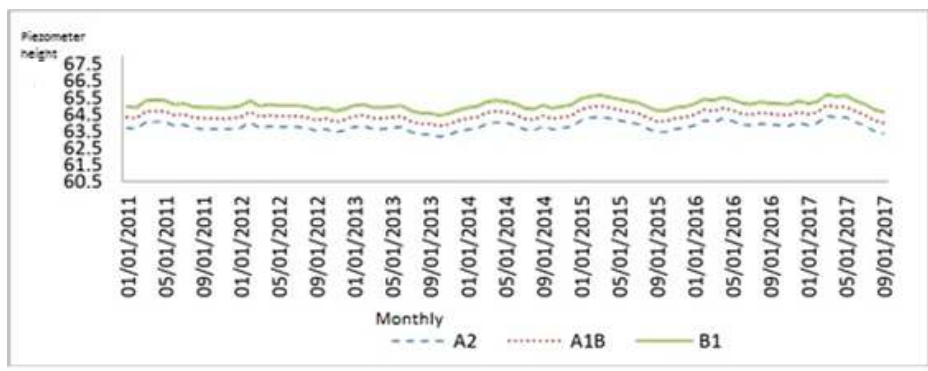

Figure 7 Neural network prediction of piezometers far from the river

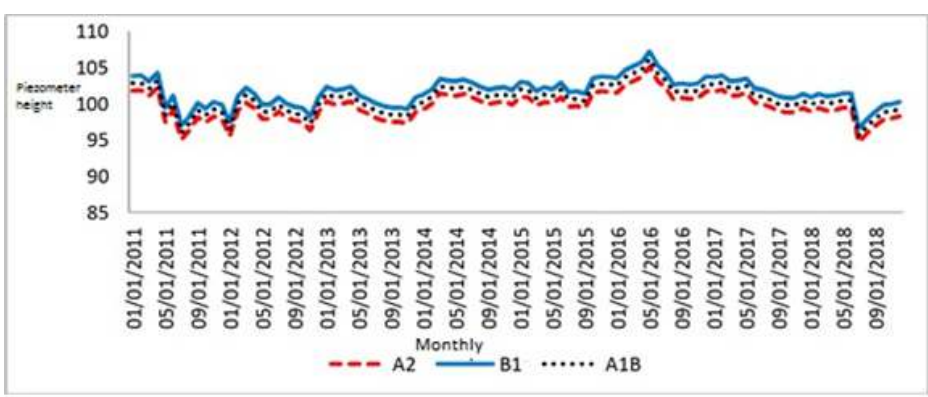

Figure 8 Predicting the neural network of piezometers near the river

\section{Discussion}

According to the study of climate change scenarios on precipitation and temperature elements in Ramhormoz plain, we found that with decreasing rainfall, a gradual decrease in the height of piezometers was obtained, which is less sensitive to precipitation changes due to the coastal aquifer. The results of this study are consistent with the studies presented by $[38,39]$. Also with $[40,41]$ studies on climate change scenarios on precipitation and temperature, in miniaturizing the precipitation parameter, [42] have examined the groundwater level, which is consistent with current studies. $[43,44]$ studies in the field of neural network are related to the leading artificial neural networks with Lunberg-Marcourt algorithm (FNN-LM). In the next step, this structure has been used to predict the water table in the region, which in the present article, using this method and the NARX neural network, the groundwater level has been predicted.

\section{Conclusion}

In this study, the effects of climate change on groundwater resources in Ramhormoz plain have been investigated. To achieve this goal, based on the meteorological variables of the GCM 
model in the study area, precipitation and temperature simulations have been performed using the micro-scale statistical model (LARS-WG) under climate change scenarios, which considers scenario A2 as the most critical case. Selected for the future and then Ramhormoz aquifer is simulated using a neural network dynamic model. Finally, based on the A2 climate change scenario, feeding and discharge information is simulated and the amount of groundwater level in future periods is investigated. The results show the significant effects of climate change on groundwater in this area, although these changes are not uniform in all parts of the aquifer. Due to the shallow depth and coastal nature of the aquifer, the topography of the plain and the direction of groundwater flow from to southeast, the highest drop in groundwater level in the aquifer is related to the southeast of the plain with a drop of about 30 meters. The lowest drop is in the northwest of Ramhormoz plain and about 10 meters.

Also, in the central part of the aquifer, the drop is about 12 meters. Also, in the eastern and southeastern part of the plain, due to the proximity of this part of the plain to the upper river, there is less attention to groundwater abstraction for agriculture. The amount of water that is currently prevailing in the southeastern part of the aquifer should be the amount of groundwater discharge in this area, taking into account a specific strategy.

\section{References}

[1] Abdollahi S, Javadinejad S, Ostad-Ali-Askari K, et al. Investigating the Effects of Landfill in AzadShahr City on the Physicochemical Properties of Groundwater. American Journal of Engineering and Applied Sciences, 2019, 12(2): 136-146. https://doi.org/10.3844/ajeassp.2019.136.146

[2] Anderson MP, Woessner WW and Hunt RJ. Applied groundwater modeling: simulation of flow and advective transport. Academic press, 2015.

[3] Andrade L, O’Dwyer J, O'Neill E, et al. Surface water flooding, groundwater contamination, and enteric disease in developed countries: A scoping review of connections and consequences. Environmental pollution, 2018, 236: 540-549. https://doi.org/10.1016/j.envpol.2018.01.104

[4] Crosbie RS, Scanlon BR, Mpelasoka FS, et al. Potential climate change effects on groundwater recharge in the High Plains Aquifer, USA. Water Resources Research, 2013, 49(7): 3936-3951. https://doi.org/10.1002/wrcr.20292

[5] Gleeson T, Wada Y, Bierkens MF, et al. Water balance of global aquifers revealed by groundwater footprint. Nature, 2012, 488(7410): 197-200. https://doi.org/10.1038/nature11295

[6] Javadinejad S, Hannah D, Ostad-Ali-Askari K, et al. The impact of future climate change and human activities on hydro-climatological drought, analysis and projections: using CMIP5 climate model simulations. Water Conservation Science and Engineering, 2019, 4(2-3): 71-88. https://doi.org/10.1007/s41101-019-00069-2

[7] Javadinejad S, Dara R and Jafary F. Health impacts of extreme events. Safety in Extreme Environments, 2020, 1: 1-11. https://doi.org/10.1007/s42797-020-00016-8

[8] Javadinejad S, Ostad-Ali-Askari K, Singh VP, et al. Reliable, Resilient, and Sustainable Water Management in Different Water Use Sectors. Water Conservation Science and Engineering, 2019, 4(2-3): 133-148. https://doi.org/10.1007/s41101-019-00073-6

[9] Javadinejad S, Eslamian S, Ostad-Ali-Askari K, et al. Relationship Between Climate Change, Natural Disaster, and Resilience in Rural and Urban Societies, In: Leal Filho W. (eds) Handbook of Climate Change Resilience. Springer, Cham, 2019. https://doi.org/10.1007/978-3-319-93336-8_189

[10] Javadinejad S. Vulnerability of water resources to climate change and human impact: scenario analysis of the Zayandeh Rud river basin in Iran, (Doctoral dissertation, University of Birmingham), 2016.

[11] Javadinejad S, Dara R and Jafary F. Climate Change Scenarios and Effects on Snow-Melt Runoff. Civil Engineering Journal, 2020, 6(9): 1715-1725. https://doi.org/10.28991/cej-2020-03091577

[12] Javadinejad S and Jafary RDF. Effect of Precipitation Characteristics on Spatial and Temporal Variations of Landslide in Kermanshah Province in Iran. Journal of Geographical Research, 2019, 2(4): $7-14$.

https://doi.org/10.30564/jgr.v2i4.1818

[13] Javadinejad S, Dara R and Jafary F. Potential impact of climate change on temperature and humidity related human health effects during extreme condition. Safety in Extreme Environments. Springer Science and Business Media LLC, 2020, 2(2): 189-195. https://doi.org/10.1007/s42797-020-00021-x

[14] Javadinejad S, Dara R and Jafary F. Analysis and prioritization the effective factors on increasing farmers resilience under climate change and drought, Agricultural research, 2020. https://doi.org/10.1007/s40003-020-00516-w 
[15] Javadinejad S, Mariwan RDMHH, Hamah A, \& et al. Analysis of Gray Water Recycling by Reuse of Industrial Waste Water for Agricultural and Irrigation Purposes. Journal of Geographical Research, 2020, 3(2): 20-24. https://doi.org/10.30564/jgr.v3i2.2056

[16] Javadinejad S, Dara R and Jafary F. Impacts of Extreme Events on Water Availability. Annals of Geographical Studies, 2019, 2(3): 16-24.

[17] Javadinejad S, Dara R and Jafary F. Gray Water Measurement and Feasibility of Retrieval Using Innova-tive Technology and Application in Water Resources Management in Isfahan-Iran. Journal of Geographical Research, 2020, 3(2): 11-19. https://doi.org/10.30564/jgr.v3i2.1997

[18] Javadinejad S, Eslamian S and Ostad-Ali-Askari K. Investigation of monthly and seasonal changes of methane gas with respect to climate change using satellite data. Applied Water Science, 2019, 9(8): 180. https://doi.org/10.1007/s13201-019-1067-9

[19] Javadinejad S, Ostad-Ali-Askari K and Eslamian S. Application of Multi-Index Decision Analysis to Management Scenarios Considering Climate Change Prediction in the Zayandeh Rud River Basin. Water Conservation Science and Engineering, 2019, 4(1): 53-70. https://doi.org/10.1007/s41101-019-00068-3

[20] Javadinejad S, Dara R and Jafary F. Taking Urgent Actions to Combat Climate Change Impacts. Annals of Geographical Studies, 2019, 2(4): 1-13.

[21] Javadinejad S, Eslamian S, Ostad-Ali-Askari K, et al. Embankments. In: Bobrowsky P., Marker B (eds) Encyclopedia of Engineering Geology. Encyclopedia of Earth Sciences Series. Springer, Cham, 2018.

https://doi.org/10.1007/978-3-319-12127-7_105-1

[22] Javadinejad S, Ostad-Ali-Askari K and Jafary F. Using simulation model to determine the regulation and to optimize the quantity of chlorine injection in water distribution networks. Modeling Earth Systems and Environment, 2019, 5(3): 1015-1023.

https://doi.org/10.1007/s40808-019-00587-x

[23] Javadinejad S, Eslamian S, Ostad-Ali-Askari K. The Analysis of the Most Important Climatic Parameters Affecting Performance of Crop Variability in a Changing Climate. International journal of hydrology science and technology, 2018.

[24] Javadinejad S. The 2008 Morpeth Flood: Continuous Simulation Model for the Wansbeck Catchment. Ebook, Grin publication, 2011.

[25] Mirramazani SM, Javadinejad S, Eslamian S, et al. The Origin of River Sediments, the Associated Dust and Climate Change. Journal of Flood Risk Management, 2017, 8(2): 149-172.

[26] Mirramazani SM, Javadinejad S, Eslamian S, et al. A Feasibility Study of Urban Green Space Design in the Form of Smart Arid Landscaping with Rainwater Harvesting. American Journal of Engineering and Applied Sciences, 2019.

[27] Javadinejad S, Dara R and Jafary F. Analysis and prioritization the effective factors on increasing farmers resilience under climate change and drought. Agricultural research, 2020. https://doi.org/10.1007/s40003-020-00516-w

[28] Javadinejad S, Dara R and Jafary F. Modelling groundwater level fluctuation in an Indian coastal aquifer. Water SA, 2020, 46(4): 665-671. https://doi.org/10.17159/wsa/2020.v46.i4.9081

[29] Javadinejad S, Dara R and Jafary F. Investigation of the effect of climate change on heat waves. Resources Environment and Information Engineering, 2020, 2(1): 54-60. https://doi.org/10.25082/REIE.2020.01.001

[30] Javadinejad S, Dara R and Jafary F. Examining the association between dust and sediment and evaluating the impact of climate change on dust and providing adaptation. Resources Environment and Information Engineering, 2020, 2(1): 61-70. https://doi.org/10.25082/REIE.2020.01.002

[31] Javadinejad S, Dara R, Jafary F, et al. Climate change management strategies to handle and cope with extreme weather and climate events. Journal of Geographical Research, 2020, 3(4): 22-28. https://doi.org/10.30564/jgr.v3i4.2324

[32] Joseph J, Ghosh S, Pathak A, et al. Hydrologic impacts of climate change: Comparisons between hydrological parameter uncertainty and climate model uncertainty. Journal of Hydrology, 2018, 566 $1-22$. https://doi.org/10.1016/j.jhydrol.2018.08.080

[33] Kløve B, Ala-Aho P, Bertrand G, et al. Climate change impacts on groundwater and dependent ecosystems. Journal of Hydrology, 2014, 518: 250-266. https://doi.org/10.1016/j.jhydrol.2013.06.037

[34] Lipczynska-Kochany E. Effect of climate change on humic substances and associated impacts on the quality of surface water and groundwater: A review. Science of the total environment, 2018, 640 1548-1565. https://doi.org/10.1016/j.scitotenv.2018.05.376

[35] Mejia JF, Huntington J, Hatchett B, et al. Linking global climate models to an integrated hydrologic model: using an individual station downscaling approach. Journal of Contemporary Water Research \& Education, 2012, 147(1): 17-27. https://doi.org/10.1111/j.1936-704X.2012.03100.x 
[36] Mohanty S, Jha MK, Raul SK, et al. Using artificial neural network approach for simultaneous forecasting of weekly groundwater levels at multiple sites. Water Resources Management, 2015, 29(15): 5521-5532. https://doi.org/10.1007/s11269-015-1132-6

[37] Nourani V, Alami MT and Vousoughi FD. Wavelet-entropy data pre-processing approach for ANNbased groundwater level modeling. Journal of Hydrology, 2015, 524: 255-269. https://doi.org/10.1016/j.jhydrol.2015.02.048

[38] Ouhamdouch S, Bahir M, Ouazar D, et al. Evaluation of climate change impact on groundwater from semi-arid environment (Essaouira Basin, Morocco) using integrated approaches. Environmental Earth Sciences, 2019, 78(15): 449. https://doi.org/10.1007/s12665-019-8470-2

[39] Salem GSA, Kazama S, Shahid S, et al. Impacts of climate change on groundwater level and irrigation cost in a groundwater dependent irrigated region. Agricultural Water Management, 2018, 208: 33-42. https://doi.org/10.1016/j.agwat.2018.06.011

[40] Schramm E and Sattary E. Scenarios for Closed Basin Water Management in the Zayandeh Rud Catchment Area. Institut für sozial-ökologische Forschung ISOE GmbH, 2014.

[41] Seifert D, Sonnenborg TO, Refsgaard JC, et al. Assessment of hydrological model predictive ability given multiple conceptual geological models. Water Resources Research, 2012, 48(6): 1-16. https://doi.org/10.1029/2011WR011149

[42] Susilo GE, Yamamoto K and Imai T. Modeling groundwater level fluctuation in the tropical peatland areas under the effect of El Nino. Procedia Environmental Sciences, 2013, 17: 119-128. https://doi.org/10.1016/j.proenv.2013.02.019

[43] Varouchakis EA and Hristopulos DT. Comparison of stochastic and deterministic methods for mapping groundwater level spatial variability in sparsely monitored basins. Environmental monitoring and assessment, 2013, 185(1): 1-19. https://doi.org/10.1007/s10661-012-2527-y

[44] Zhang X, Liu P, Cheng L, et al. A back-fitting algorithm to improve real-time flood forecasting. Journal of Hydrology, 2018, 562: 140-150. https://doi.org/10.1016/j.jhydrol.2018.04.051 